\title{
Double or Triple Therapy in Chronic Obstructive Pulmonary Disease
}

\author{
Mario Cazzola, MD, FERS'1, Paola Rogliani, MD ${ }^{1}$ and Maria G. Matera, MD, PhD, FERS ${ }^{2}$
}

${ }^{1}$ Department of Experimental Medicine and Surgery, Chair of Respiratory Medicine, University of Rome "Tor Vergata", Rome, Italy; ${ }^{2}$ Department of Experimental Medicine, Chair of Pharmacology, University of Campania "Luigi Vanvitelli", Naples, Italy

\section{ABSTRACT}

Although the Global Initiative for Chronic Obstructive Lung Disease (GOLD) strategy recommends triple therapy involving long-acting muscarinic antagonists (LAMAs), long-acting $\beta_{2}$-agonists (LABAs) and inhaled corticosteroids (ICS) only for further advanced patients, particularly for those at a high risk for exacerbation (GOLD D), triple therapy is widely prescribed in real-life management of chronic obstructive pulmonary disease (COPD), even in patients with mild or moderate COPD severity, likely because physicians prefer to prescribe a full treatment to ensure the best care to their patients. While the available clinical evidence on triple therapy has greatly increased in recent years, there is still no solid evidence to indicate whether and when addition of an ICS to the LABA/LAMA combination provides additional clinical value. Therefore, a strong recommendation can still not be generated but the results of four recent pivotal triple therapy studies support the possibility that this treatment option should be considered also for GOLD B patients. (BRN Rev. 2018;4(4):287-303) Corresponding author: Mario Cazzola, mario.cazzola@uniroma2.it

Key words: Chronic obstructive pulmonary disease. Dual bronchodilation. Triple therapy. 


\section{INTRODUCTION}

The Global Initiative for Obstructive Lung Disease (GOLD) strategy recommends treating patients at lower risk of exacerbations (group B) with a long-acting bronchodilator, escalating to dual bronchodilation if symptoms persist, but dual bronchodilation is the first-choice initial treatment for patients of GOLD D, i.e. patients with COPD assessment test (CAT) $\geq 10$ units plus $\geq 2$ moderate exacerbations and/or $\geq 1$ severe exacerbation in the previous year ${ }^{1}$. Actually, all long-acting muscarinic receptor antagonist (LAMA)/long-acting $\beta_{2}$-agonist (LABA) combinations are always more effective than the LAMA or LABA alone in terms of improvement in trough forced expiratory volume in one second $\left(\mathrm{FEV}_{1}\right)$, Transition Dyspnoea Index (TDI) and St. George's Respiratory Questionnaire (SGRQ) scores ${ }^{2}$. There is also some evidence that LAMA/LABA combinations result in fewer acute exacerbations of COPD (AECOPDs) and pneumonia, and larger improvement in $\mathrm{FEV}_{1}$ than LABA/inhaled corticosteroid (ICS) combinations ${ }^{3}$.

The GOLD strategy also recommends an escalation to a triple therapy, which adds ICS to dual-bronchodilator therapy or a LAMA to existing LABA/ICS, only after having maximised bronchodilator treatment with LAMA/ LABA regimens and be limited to patients with more symptomatic GOLD D, because there is no conclusive evidence on the superiority of triple therapy over other therapeutic options, particularly in patients at low risk of exacerbations ${ }^{1}$.

Nevertheless, triple therapy is widely prescribed in real-life management of COPD, even in patients with mild or moderate COPD severity, as demonstrated by retrospective observational studies in the United States ${ }^{4}$ (US) and United Kingdom (UK) ${ }^{5,6}$.

Several independent factors, such as being older, having undergone pulmonary or spirometry evaluation or having been placed on LABA/ ICS fixed-dose combination (FDC) therapy at diagnosis, the presence of comorbid asthma and the possibility of a better control of symptoms can predict prescriptions of triple therapy in clinical practice regardless of the severity of airflow limitation ${ }^{7,8}$. However, there is also real-world evidence that patients with COPD are more likely to initiate open-triple therapy following initiation with LAMA monotherapy, compared with LABA/ICS therapy ${ }^{9}$. It has been speculated that, at least in Sweden, the widespread use of triple therapy is due to the chronic characteristics of the disease, with a documented high proportion of persistent breathlessness in spite of maximum optimised treatment ${ }^{10}$. Other potential explanations may be increased availability of inhaled therapy in different devices and combinations, overtreatment due to heavy marketing from pharmaceutical companies, and increased awareness and implementation of GOLD ABCD recommendations.

In any case, the use of triple therapy is not only a practice of general practitioners; also pulmonologists often prefer to use triple therapy, even in patients who are not suffering from severe COPD ${ }^{11}$. The Adelphi Respiratory Disease Specific Programme documented that considerable proportions of patients in the low risk groups (GOLD A and B) were currently receiving LABA/ICS, either alone or in combination with a LAMA $^{12}$. Actually, the percentage of 3813 patients with COPD recruited 
in the survey by an equal number of primary care physicians and pulmonologists working in the US and five European countries (France, Germany, Italy, Spain and the UK) who were receiving $\mathrm{LABA} / \mathrm{ICS}+\mathrm{LAMA}$ or $\mathrm{LABA}+\mathrm{ICS}$ + LAMA, was $11.8 \%$ in patients with GOLD A and $23.8 \%$ in those with GOLD B. This prescriptive behaviour is likely due to the confidence that physicians have in starting a full treatment to ensure the best care to their patients ${ }^{13}$.

\section{TRIPLE THERAPY ADMINISTERED USING MULTIPLE INHALERS}

The confidence of physicians that triple therapy provides the best care to their patients should be based on personal clinical experience but, above all, on scientific evidence. Meta-analyses of published data (Table 1) or observational studies are useful to help in understanding the real role of triple therapy in COPD.

In 2011, a Cochrane review ${ }^{14}$ was able to examine only three studies, two lasting three months and the third one year ${ }^{17}$. Heterogeneity and wide confidence intervals did not draw any conclusions from the outcomes except for an improvement in the health-related quality of life (HRQoL) scores and lung function for triple therapy versus tiotropium alone. However, the Canadian Optimal Therapy of COPD (OPTIMAL) study showed that the free LAMA + LABA/ICS combination, compared with LAMA alone or LABA/ICS, caused the greatest reduction in hospitalisations due to $\mathrm{AECOPD}^{17}$.

A second Cochrane review published in $2016^{18}$ added other three studies, one lasting three months ${ }^{19}$ and the other two six months ${ }^{20,21}$. This review showed an evidence of moderate quality that combining tiotropium + LABA/ICS compared with tiotropium monotherapy was able to decrease hospital admission. Lung function was slightly, but significantly, better in the combined therapy group, but the improvement in HRQoL with combined therapy was of low-quality evidence. Evidence was also insufficient to support the benefit of tiotropium + LABA/ICS for mortality and exacerbations (moderate- and low-quality evidence, respectively).

The Italian observational study Long-term outcomes and adverse events of therapy with inhaled corticosteroids, long-acting $\beta_{2}$-agonists and anticholinergic drugs in hospitalised patients with COPD (OUTPUL) documented that tiotropium + LABA/ICS did not reduce AECOPDs within a one-year follow-up period compared with LABA/ICS alone among patients discharged after a COPD exacerbation, although it was more effective in preventing moderate exacerbations compared to LABA/ICS in frequent exacerbators ${ }^{22}$. Also a retrospective cohort study using a National Health Service (NHS) database of UK patients with COPD supported the signal indicating that tiotropium + LABA/ICS may confer benefits in reducing all-cause mortality, exacerbations requiring oral glucocorticoids (-29\%), and hospital admissions (-15\%) compared with $\mathrm{LABA} / \mathrm{ICS}^{23}$.

The only information derived from the Cochrane reviews and pooled analysis of the UK primary data was the possible advantage of adding tiotropium in patients on regular treatment with LABA/ICS. However, a post hoc analysis of pooled data from four 12-week 
TABLE 1. Trials with triple therapy administered using multiple inhalers

\begin{tabular}{|c|c|c|c|c|}
\hline Study & Patients & Study design & Therapy & Key findings \\
\hline $\begin{array}{l}\text { Cazzola } \\
\text { et al. } .^{15}\end{array}$ & $\begin{array}{l}90 \text { patients with } \\
\text { well-con- } \\
\text { trolled COPD }\end{array}$ & $\begin{array}{l}\text { Randomised, } \\
\text { double-blind, } \\
\text { double-dummy, } \\
\text { parallel-group trial } \\
\text { over } 12 \text { weeks }\end{array}$ & $\begin{array}{l}\text { SFC } 50 / 500 \mu \mathrm{g} \\
\text { twice daily } \\
\text { TIO } 18 \mu \mathrm{g} \text { once } \\
\text { daily } \\
\text { SFC } 50 / 500 \mu \mathrm{g} \\
\text { twice daily + TIO } \\
18 \mu \mathrm{g} \text { once daily }\end{array}$ & $\begin{array}{l}\text { Significant }(p<0.05) \text { improvements in trough } \mathrm{FEV}_{1} \text { above } \\
\text { baseline }(140 \mathrm{~mL} \text { in the SFC group, } 141 \mathrm{~mL} \text { in the TIO group, } \\
\text { and } 186 \mathrm{~mL} \text { in SFC + TIO group } \\
\text { Greater improvements in dyspnoea with TIO and SFC+TIO (VAS } \\
\text { scores decreased by }-2.31 \text {, and }-2.34 \text {, respectively), than SFC } \\
(-2.00 \text { but differences between the three treatments } \\
\text { statistically not significant }(p>0.05)\end{array}$ \\
\hline $\begin{array}{l}\text { Welte } \\
\text { et al. }{ }^{16}\end{array}$ & $\begin{array}{l}660 \text { patients } \\
\text { with severe } \\
\text { or very severe } \\
\text { COPD and a } \\
\text { history of } \\
\text { exacerbations } \\
\text { requiring } \\
\text { systemic } \\
\text { steroids and/ } \\
\text { or antibiotics }\end{array}$ & $\begin{array}{l}\text { Randomised, } \\
\text { double-blind, } \\
\text { parallel-group, } \\
\text { multi-centre trial over } \\
12 \text { weeks }\end{array}$ & $\begin{array}{l}\text { TIO } 18 \mu \mathrm{g} \text { once } \\
\text { daily }+ \text { FF/BUD } \\
9 / 320 \mu \mathrm{g} 1 \text { twice } \\
\text { daily } \\
\text { TIO } 18 \mu \mathrm{g} \text { once } \\
\text { daily }\end{array}$ & $\begin{array}{l}\text { Triple therapy significantly improved pre-dose } \mathrm{FEV}_{1} \text { compared } \\
\text { with TIO (6\% increase [65 mL]; } p<0.001) \\
\text { Triple therapy significantly improved post-dose FEV } 111 \% \\
\text { increase [123 and } 131 \mathrm{~mL} \text { at } 5 \text { and } 60 \text { min post-dose, } \\
\text { respectively]; both } \mathrm{p}<0.001 \text { ) and reduced exacerbation rate } \\
\text { versus TIO (rate ratio, } 0.38 ; 95 \% \text { CI: } 0.25-0.57 ; p<0.001) \\
\text { Triple therapy significantly improved SGR0 total score (mean } \\
\text { difference: }-2.3 \text { units; } \mathrm{p}=0.023 \text { ) and symptoms (as measured } \\
\text { by GCSO [mean difference in scores for chest tightness and } \\
\text { breathlessness ranging from }-0.104 \text { to }-0.185 \text { at } 5 \text { min and } \\
15 \text { min post-dose; all } p<0.05 \text { ] and COPD symptoms rating } \\
\text { scale [mean difference in scores ranging from }-0.142 \text { to }-0.161 \\
\text { for breathlessness, chest tightness, night-time awakenings } \\
\text { and cough; all } p<0.001] \text { ) versus TIO }\end{array}$ \\
\hline $\begin{array}{l}\text { Aaron } \\
\text { et al. }{ }^{17}\end{array}$ & $\begin{array}{l}449 \text { patients } \\
\text { with a clinical } \\
\text { history of } \\
\text { moderate or } \\
\text { severe COPD }\end{array}$ & $\begin{array}{l}\text { Randomised, } \\
\text { double-blind, } \\
\text { placebo-controlled, } \\
\text { parallel-group trial } \\
\text { over } 52 \text { weeks }\end{array}$ & $\begin{array}{l}\text { TIO } 18 \mu \mathrm{g} \text { once } \\
\text { daily + SFC } \\
50 / 500 \mu \mathrm{g} \text { twice } \\
\text { daily } \\
\text { TIO } 18 \mu \mathrm{g} \text { once } \\
\text { daily + salmeter- } \\
\text { ol } 50 \mu \mathrm{g} \text { twice } \\
\text { daily } \\
\text { TIO } 18 \mu \mathrm{g} \text { once } \\
\text { daily }\end{array}$ & $\begin{array}{l}\text { No significant difference in the rate of patients who experi- } \\
\text { enced } \geq 1 \text { COPD exacerbation }(60.0 \%, 64.8 \% \text { and } 62.8 \% \text { of } \\
\text { patients in SFC + TIO, TIO + SAL and TIO groups, respectively) } \\
\text { No significant difference in TDI total score (mean scores } 1.84,1.40 \\
\text { and } 1.78 \text { units, respectively), rate of exacerbations (mean } \\
\text { exacerbations per patient year } 1.37,1.75 \text { and } 1.61 \text {, respectively) or } \\
\text { time-to-first exacerbation ( } 217,128 \text { and } 130 \text { days, respectively) } \\
\text { Triple therapy, compared with TIO, significantly improved } \\
\text { pre-bronchodilator FEV (increase of } 86 \mathrm{~mL} \text { versus } 27 \mathrm{~mL} \text {; } \\
p=0.049 \text { ) and SGRO total score (change in score }-8.6 \text { units vs. } \\
-4.5 \text { units; } p=0.01 \text { ) }\end{array}$ \\
\hline $\begin{array}{l}\text { Hoshino } \\
\text { et al. } .^{19}\end{array}$ & 36 patients & $\begin{array}{l}\text { Open, randomised, } \\
\text { parallel-group study } \\
\text { over } 12 \text { weeks }\end{array}$ & $\begin{array}{l}\text { SFC } 50 / 250 \mu \mathrm{g} \\
\text { twice daily }+ \text { TIO } \\
18 \mu \mathrm{g} \text { once daily } \\
\text { TIO } 18 \mu \mathrm{g} \text { once } \\
\text { daily }\end{array}$ & $\begin{array}{l}\text { Triple therapy significantly decreased airway wall area corrected } \\
\text { for body surface area; percentage wall area and absolute wall } \\
\text { thickness ( } p<0.05 ; p<0.01 \text { and } p<0.01 \text {, respectively) and } \\
\text { increased luminal area corrected for body surface area ( } p<0.01 \text { ) } \\
\text { Triple therapy significantly improved SGRO total score versus TIO }\end{array}$ \\
\hline $\begin{array}{r}\text { Hanania } \\
\text { et al. } .^{20}\end{array}$ & $\begin{array}{l}342 \text { patients } \\
\text { with a clinical } \\
\text { history of } \\
\text { moderate- } \\
\text { to-severe } \\
\text { COPD }\end{array}$ & $\begin{array}{l}\text { Randomised, } \\
\text { double-blind, } \\
\text { parallel-group, } \\
\text { multi-centre study } \\
\text { over } 24 \text { weeks }\end{array}$ & $\begin{array}{l}\text { SFC } 50 / 250 \mu \mathrm{g} \\
\text { twice daily }+ \text { TIO } \\
18 \mu \mathrm{g} \text { once daily } \\
\text { TIO } 18 \mu \mathrm{g} \text { once } \\
\text { daily }\end{array}$ & $\begin{array}{l}\text { Triple therapy significantly improved pre-dose } \mathrm{FEV}_{1} \text { compared } \\
\text { with TIO (LSM difference: } 115 \mathrm{~mL} ; \mathrm{p}<0.001 \text { ) } \\
\text { Triple therapy significantly improved rescue medication use } \\
\text { compared with TIO (LSM difference: }-0.6 \text { [SE } 0.24] ; p=0.01 \text { ) } \\
\text { There were no significant differences in health status (LSM } \\
\text { differences in CRO-SAS domain scores ranging from } 0.02 \text { to } \\
0.2 \text { ) or exacerbation rate }(0.14 \text { versus } 0.17 \text { for SFC + TIO and } \\
\text { TIO, respectively }\end{array}$ \\
\hline Jung et al. ${ }^{21}$ & $\begin{array}{r}479 \text { patients } \\
\text { with COPD }\end{array}$ & $\begin{array}{l}\text { Randomised, open-la- } \\
\text { bel, multi-centre, } \\
\text { two-arm, parallel } \\
\text { study over } 24 \text { weeks }\end{array}$ & $\begin{array}{l}\text { SFC } 50 / 250 \mu \mathrm{g} \\
\text { twice daily + TIO } \\
18 \mu \mathrm{g} \text { once daily } \\
\text { TIO } 18 \mu \mathrm{g} \text { once daily }\end{array}$ & $\begin{array}{l}\text { Triple therapy significantly improved pre-bronchodilator } \mathrm{FEV}_{1} \\
\text { versus TIO ( } 90 \mathrm{~mL} \text { versus } 38 \mathrm{~mL} ; \mathrm{p}=0.005 \text { ) } \\
\text { Triple therapy significantly improved SGRQ-C scores versus TIO } \\
\text { (mean change in score: }-6.6 \text { units versus }-1.5 \text { units; } \mathrm{p}=0.001 \text { ) }\end{array}$ \\
\hline $\begin{array}{r}\text { Vincken } \\
\text { et al. }{ }^{26}\end{array}$ & 280 patients & $\begin{array}{l}\text { Multicentre, dou- } \\
\text { ble-blind, parallel } \\
\text { group study over } \\
12 \text { weeks }\end{array}$ & $\begin{array}{l}\text { GB } 50 \mu \mathrm{g}+\text { IND } \\
150 \mu \mathrm{g}+\mathrm{ICS} \\
\text { IND } 150 \mu \mathrm{g}+\text { ICS }\end{array}$ & 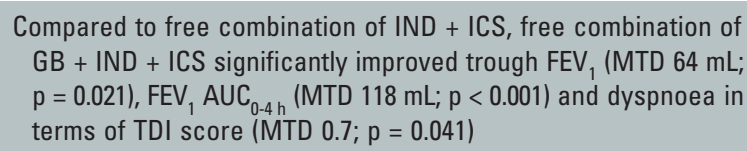 \\
\hline
\end{tabular}

$\mathrm{AUC}_{0-4 \mathrm{~h}}$ : area under the curve from 0 to 4h; BUD: budesonide; Cl: confidence interval; COPD: chronic obstructive pulmonary disease; CRO-SAS: Chronic Respiratory Disease Questionnaire-Self-Administered Standardised; FEV ; forced expiratory volume in one second; FF: formoterol fumarate; GB: glycopyrronium bromide; GCSQ: global chest symptoms questionnaire; ICS: inhaled corticosteroid; IND: indacaterol; LSM: least squares mean; MTD: mean treatment difference; SAL: salmeterol; SE: standard error; SFC: salmeterol/fluticasone propionate combination; SGRQ: St George's Respiratory Questionnaire; SGRQ-C: St George's Respiratory Questionnaire for COPD patients;

TDI: Transition Dispnoea Index; TIO: tiotropium; VAS: visual analogue scale. 
randomised controlled trials (RCTs) confirmed that in GOLD D patients, adding umeclidinium (UMEC) $62.5 \mu \mathrm{g}$ to LABA/ICS (vilanterol [VI]/ fluticasone furoate [FF] 25/100 $\mu$ g or salmeterol/fluticasone propionate 50/250 $\mu \mathrm{g}$ ) resulted in clinically important (> $100 \mathrm{~mL}$ ) improvements in lung function, reduced rescue medication use, reduced the risk of moderate-to-severe AECOPDs, and improved the SGRQ total score compared with placebo + LABA/ICS ${ }^{24}$. When analysing GOLD B and GOLB D patients, improvements in lung function with UMEC $62.5 \mu \mathrm{g}+\mathrm{LABA} / \mathrm{ICS}$ versus placebo + LABA/ ICS were numerically greater in patients with better lung function at study entry, i.e. patients with GOLD B versus those with GOLD D.

The introduction of double bronchodilation has offered an alternative: LAMA/LABA FDCs to combine with an ICS in another inhaler. Although a network meta-analysis of 23 RCTs reported that indacaterol (IND) + tiotropium is expected to be comparable to triple therapies when focused on $\mathrm{FEV}_{1}$ after 12-week treatment ${ }^{25}$, a post hoc analysis from the GLycopyrronium bromide in COPD airWays clinical study 6 (GLOW6) study showed that over 12 weeks, the free triple combination with glycopyrronium bromide (GB) + IND + ICS induced significantly better improvements in lung function and dyspnoea compared to the free double combination (IND + ICS) in symptomatic patients with moderate-to-severe COPD ${ }^{26}$.

This is interesting information for the treatment of patients with COPD, to whom we must guarantee mainly appropriate administration of the bronchodilators, with a more controversial role for ICS. For this reason, as rightly pointed out by Lopez-Campos et al. ${ }^{27}$, due to the lack of specific clinical trials, it seems more reasonable to use the combination of LAMA/LABA + ICS in COPD than to add a LAMA to LABA/ICS. Actually, a Scottish real-life retrospective analysis showed that in patients exposed to ICS, concomitant use of LAMA alone as dual therapy or in combination with LABA as triple therapy was associated with reductions in all-cause mortality, while concomitant use of LABA without LAMA conferred no reduction ${ }^{28}$. Moreover, only triple therapy was found to confer benefits on cardiovascular mortality. On the other side, in the Withdrawal of inhaled glucocorticoids and exacerbations of COPD (WISDOM) study, although the withdrawal of ICS induced a trend toward an increased risk for severe exacerbations, this did not reach significant levels ${ }^{29}$.

In 2015, a systematic review and a meta-analysis that compared triple therapy versus dual bronchodilator therapy ${ }^{30}$ could include only two studies: the OPTIMAL trial ${ }^{17}$, and the WISDOM study ${ }^{29}$. There was no difference in all-cause mortality, all-cause admission, exacerbation, adverse effect, and serious adverse effect between the dual-bronchodilator and the triple therapy arms. The triple therapy was slightly associated with favourable impacts on both the FEV $\mathrm{F}_{1}$ and the SGRQ total score in both studies, although the observed difference did not reach the minimum clinically important difference (MCID) in either (i.e. $50 \mathrm{~mL}$ for $\mathrm{FEV}_{1}$ and four points for the total SGRQ score).

\section{PHARMACOLOGICAL RATIONALE FOR TRIPLE INHALED THERAPY}

The favourable pharmacological interaction between inhaled $\beta_{2}$-agonists and corticosteroids 
in COPD is a concept that has been developed for a long time ${ }^{31}$. We documented that combining beclometasone dipropionate (BDP) with formoterol furoate (FF) at 100:6 concentration-ratio not only improved the effectiveness of FF, but also elicited a synergistic bronchorelaxant effect in both medium and small airways ${ }^{32}$. Multiple mechanisms could account for the clinical efficacy of LABA/ICS combination therapies ${ }^{33}$. In particular, glucocorticoids increase the numbers of $\beta_{2}$-adrenoceptors and $\beta_{2}$-agonists induce direct bronchodilation, and act on glucocorticoid receptors to increase the anti-inflammatory effects of glucocorticoids ${ }^{33}$. The exact effect of LABAs on ICS is uncertain, but a synergistic interaction may likely exist ${ }^{31}$. While the molecular basis of synergy remains unclear, it is probable that mechanistic interpretations must accommodate gene-specific regulation ${ }^{34}$. In any case, we strongly believe that mechanisms affecting airway obstruction, inflammation, structural changes, and mucociliary dysfunction could all together account for the clinical efficacy of LABA/ICS combination therapies ${ }^{31}$.

Our group has repeatedly described the strong pharmacological rationale that supports the use of double bronchodilation ${ }^{35,36}$, and has also widely documented with translational studies that the combination of a LABA with a LAMA leads to a synergistic release of the airway smooth muscle (ASM) $)^{37,38}$.

We have also demonstrated that the acute administration of BDP and GB induces a significant relaxation of passively sensitised ASM pre-contracted with histamine, by causing submaximal/maximal inhibition of the contractile tone in both medium bronchi and bronchioles ${ }^{39}$. However, the LAMA/ICS combination synergistically enhanced only the relaxation of passively sensitised medium and small bronchi. These pre-clinical findings may suggest that there is no advantage in combining a LAMA and an ICS in COPD patients.

The evidence of a true pharmacological advantage deriving from the combination of LAMA + LABA + ICS is still absent, but it could be supposed that the possible synergism of action with the LABA + ICS might be added to the well-documented synergistic effect of the LAMA + LABA combinations. Unfortunately, so far there is no study evaluating the in vitro pharmacological interactions of triple therapy.

\section{TRIPLE THERAPIES UNDER DEVELOPMENT}

Although the reviewed evidence is not solid enough to support the regular use of triple therapy in COPD, it is likely that the usual prescriptive behaviour of physicians that favours the triple therapy even in those patients with COPD whose airflow limitation is not severe is the main reason why the pharmaceutical industry has interest in developing LAMA/LABA/ICS FDC.

Triohale (tiotropium $18 \mu \mathrm{g}+$ FF $12 \mu \mathrm{g}+$ ciclesonide $400 \mu \mathrm{g}$ ) was the first triple combination to enter the market, at least in India. A 24-week, open-label, prospective, non-comparative, multicentre, real-world study, which enrolled patients with COPD requiring triple therapy as assessed by physician, documented that lung function and symptoms significantly 
TABLE 2. Pharmacological characteristics of long-acting $\beta_{2}$ (LABAs) and long-acting muscarinic antagonists (LAMAs) versus inhaled corticosteroids (ICS) included in triple combinations under development ${ }^{36,65}$

\begin{tabular}{|c|c|c|c|c|c|c|}
\hline \multicolumn{7}{|c|}{ LABAs } \\
\hline & \multicolumn{4}{|c|}{$\beta_{2}-A R$} & \multirow[t]{2}{*}{$\beta_{1}-A R$} & \multirow[t]{2}{*}{$\beta_{2} / \beta_{1}$ ratio } \\
\hline & pKi & $\begin{array}{c}\text { IA } \\
\text { (\% isoprenaline })\end{array}$ & $\begin{array}{l}\text { Onset of action } \\
\left(t_{1 / 2}, \mathrm{~min}\right)\end{array}$ & $\begin{array}{c}\text { Duration of action } \\
\text { (h) }\end{array}$ & & \\
\hline Formoterol & 8.06 & 95.0 & 5.9 & 0.93 & 6.10 & 130 \\
\hline Vilanterol & 9.42 & 70.0 & 3.45 & NA & NA & 2400 \\
\hline
\end{tabular}

\begin{tabular}{|c|c|c|c|c|c|c|c|c|c|}
\hline \multicolumn{10}{|c|}{ LAMAs } \\
\hline & \multicolumn{4}{|c|}{$\mathrm{M}_{3} \mathrm{mAChR}$} & \multicolumn{2}{|c|}{$M_{1} \mathrm{mAChR}$} & \multicolumn{2}{|c|}{$\mathrm{M}_{2} \mathrm{mAChR}$} & \multirow[t]{2}{*}{$M^{3} / M^{2}$ ratio } \\
\hline & $\mathbf{p K i}$ & $\begin{array}{c}K_{\text {off }} \\
\left(h^{-1}\right)\end{array}$ & $\begin{array}{c}\text { Onset } \\
\text { of action } \\
\left(t_{1 / 2}, \mathrm{~min}\right)\end{array}$ & $\begin{array}{l}\text { Duration } \\
\text { of action } \\
\text { (h) }\end{array}$ & pKi & $\begin{array}{c}K_{\text {off }} \\
\left(h^{-1}\right)\end{array}$ & $\mathbf{p K i}$ & $\begin{array}{c}K_{\text {off }} \\
\left(h^{-1}\right)\end{array}$ & \\
\hline Glycopyrronium & 9.28 & 0.11 & 8.72 & 6.1 & 9.77 & NA & 9.09 & 1.84 & 16.5 \\
\hline Umeclidinium & 9.80 & 0.53 & 9.0 & 1.37 & 9.80 & NA & 9.82 & 4.44 & 8.7 \\
\hline
\end{tabular}

\begin{tabular}{|c|c|c|c|c|c|c|c|}
\hline \multicolumn{8}{|c|}{ ICS } \\
\hline & $\begin{array}{c}\text { Relative } \\
\text { glucocorticoid } \\
\text { receptor binding } \\
\text { affinity* }\end{array}$ & $\begin{array}{l}\text { Lipophilicity } \\
\left(\log P^{* *}\right)\end{array}$ & 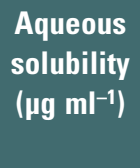 & $\begin{array}{l}\text { PPB } \\
(\%)\end{array}$ & Vss I & $\underset{\left(h^{-1}\right)}{C L}$ & $\begin{array}{c}F \\
(\%)\end{array}$ \\
\hline Beclometasone dipropionate & $53(1345)$ & $4.59(3.27)$ & $0.13(15.5)$ & 95.9 & 424 & 120 & $\begin{array}{l}62^{\mathrm{CFC}} \\
82^{\mathrm{HFA}} \\
41^{\text {oral }}\end{array}$ \\
\hline Budesonide & 935 & 2.32 & 16 & 91.4 & 180 & 84 & $\begin{array}{l}39^{\mathrm{DPI}} \\
11^{\text {oral }}\end{array}$ \\
\hline Fluticasone furoate & 2989 & 4.17 & 0.03 & 99.7 & 608 & 65 & $\begin{array}{l}15^{\mathrm{DPI}} \\
1^{\text {oral }}\end{array}$ \\
\hline
\end{tabular}

*Glucocorticoid receptor binding affinity is relative to dexamethasone where dexamethasone affinity $=100$.

** Log $P$ values are defined as the $\log _{10}$ of the octanol/water partition coefficient.

$\beta_{2}$-AR: $\beta_{2}$-adrenergic receptors; CFC: chlorofluorocarbon; CL: plasma clearance; DPI: dry powder inhaler; F: absolute bioavailability determined in healthy subjects;

HFA: hydrofluoroalkane; IA: intrinsic activity; $K_{\text {off }}$ d dissociation rate; NA: not available in human tissue; $M_{3} m A C h R: M_{3}$ muscarinic acetylcholine receptor; pKi: the negative logarithm to base 10 of the equilibrium dissociation constant of a ligand determined in inhibition studies; PPB: plasma protein binding; $t_{1 / 2}$ : residence half-life; Vss: volume of distribution at steady state.

improved in patients with COPD, independent of their smoking history ${ }^{40}$.

There is much more information on three other triple combinations that are still under development. Detailed pharmacological characteristics of LAMAs, LABAs and ICS included in these FDCs are reported in table 2. Table 3 describes the main trials already published.

\section{a. Glycopyrronium bromide/ formoterol fumarate/beclometasone dipropionate combination}

A GB/FF/BDP FDC is under clinical development as a hydrofluoroalkane (HFA) solution delivered via a pressurised metered dose inhaler (pMDI) with a nominal dose per actuation of $12.5,6$, and $100 \mu \mathrm{g}$ of GB, FF, and BDP, 
TABLE 3. Trials with triple therapy administered in a single inhaler

\begin{tabular}{|c|c|c|c|c|}
\hline Study & Patients & Study design & Therapy & Key findings \\
\hline \multicolumn{5}{|c|}{ Glycopyrronium bromide/formoterol fumarate/beclometasone dipropionate } \\
\hline $\begin{array}{l}\text { Singh et al. } \\
(\text { TRIDENT) }\end{array}$ & $\begin{array}{l}178 \text { patients with } \\
\text { moderate-to-severe } \\
\text { COPD }\end{array}$ & $\begin{array}{l}\text { Multicentre, } \\
\text { double-blind, } \\
\text { randomised, } \\
\text { active- and } \\
\text { placebo-controlled, } \\
\text { four-way crossover } \\
\text { study over seven } \\
\text { days }\end{array}$ & $\begin{array}{l}\text { GB } 12.5,25 \text { or } 50 \mu \mathrm{g} \\
\text { twice daily added } \\
\text { to regular FF/BDP } \\
12 / 200 \mu \mathrm{g} \text { twice } \\
\text { daily }\end{array}$ & $\begin{array}{l}\text { Mean } \mathrm{FEV}_{1} \mathrm{AUC}_{0-12} \text { significantly higher }(\mathrm{p}<0.001) \text { for all } \\
\mathrm{GB} \text { doses plus FF/BDP compared to FF/BDP alone, with } \\
\text { the difference for the } 25 \text { and } 50 \mu \mathrm{g} \text { doses being } \\
\text { clinically relevant }(\geq 100 \mathrm{~mL})\end{array}$ \\
\hline $\begin{array}{l}\text { Singh et al. } \\
(\text { TRILOGY) }\end{array}$ & $\begin{array}{l}1368 \text { patients with a } \\
\text { post-bronchodilator } \\
\mathrm{FEV}_{1}<50 \%, \geq 1 \\
\text { moderate-to-severe } \\
\text { COPD exacerbation } \\
\text { in the previous } \\
12 \text { months, CAT total } \\
\text { score } \geq 10 \text {, and a } \\
\text { BDI focal score } \leq 10\end{array}$ & $\begin{array}{l}\text { Multicentre, } \\
\text { randomised, } \\
\text { parallel group, } \\
\text { double blind, } \\
\text { active-controlled } \\
\text { study over } \\
52 \text { weeks }\end{array}$ & $\begin{array}{l}\text { GB/FF/BDP } \\
\text { 25/12/200 } \mu \mathrm{g} \\
\text { twice daily } \\
\text { FF/BDP 12/200 } \mu \mathrm{g} \\
\text { twice daily }\end{array}$ & $\begin{array}{l}\text { Triple therapy significantly improved pre-dose } \mathrm{FEV}_{1} \\
\text { (adjusted mean difference: } 81 \mathrm{~mL} ; \mathrm{p}<0.001 \text { ) and } \\
\text { 2-hour post-dose } \mathrm{FEV}_{1} \text { (adjusted mean difference: } \\
117 \mathrm{~mL} ; \mathrm{p}<0.001 \text { ) compared with FF/BDP } \\
\text { Triple therapy did not significantly improve TDI total } \\
\text { score compared with FF/BDP (mean treatment } \\
\text { difference: } 0.21 \text { units) } \\
\text { Triple therapy significantly improved SGR0 total score } \\
\text { at Weeks } 4,12 \text { and } 52 \text { versus FF/BDP (mean treatment } \\
\text { difference at week } 52 \text { : }-1.69 \text { units; } \mathrm{p}=0.029 \text { ) } \\
\text { Triple therapy significantly reduced the rate of } \\
\text { moderate-to-severe exacerbations versus FF/BDP (rate } \\
\text { ratio } 0.77 ; 95 \% \text { Cl: } 0.65 \text { to } 0.92 ; \mathrm{p}=0.005 \text { ) } \\
\text { In patients with }>1 \text { exacerbation, triple therapy } \\
\text { significantly reduced the rate of moderate-to-severe } \\
\text { exacerbation versus FF/BDP (rate ratio } 0.67 ; 95 \% \mathrm{Cl} \text { : } \\
0.48 \text { to } 0.94 ; \mathrm{p}=0.019 \text { ) }\end{array}$ \\
\hline $\begin{array}{l}\text { Vestbo et al. } \\
\text { (TRINITY) }^{43}\end{array}$ & $\begin{array}{l}2691 \text { patients with a } \\
\text { post-bronchodilator } \\
\mathrm{FEV}_{1}<50 \%, \geq 1 \\
\text { moderate-to-severe } \\
\text { COPD exacerbation } \\
\text { in the previous } \\
12 \text { months, CAT total } \\
\text { score } \geq 10\end{array}$ & $\begin{array}{l}\text { Multicentre, } \\
\text { randomised, } \\
\text { parallel group, } \\
\text { double-blind, } \\
\text { double-dummy, } \\
\text { active-controlled } \\
\text { trial over } 52 \text { weeks }\end{array}$ & $\begin{array}{l}\text { GB/FF/BDP } \\
25 / 12 / 200 \mu \mathrm{g} \\
\text { twice daily } \\
\text { TIO } 18 \mu \mathrm{g} \text { once } \\
\text { daily } \\
\text { FF/BDP } 12 / 200 \mu \mathrm{g} \\
\text { twice daily + TIO } \\
18 \mu \mathrm{g} \text { once daily }\end{array}$ & $\begin{array}{l}\text { GB/FF/BDP significantly reduced the rate of moderate } \\
\text { or severe exacerbations compared with TIO (rate ratio } \\
0.80 ; 95 \% \text { CI: } 0.69 \text { to } 0.92 ; \mathrm{p}=0.0025 \text { ) } \\
\text { GB/FF/BDP significantly improved pre-dose FEV } \\
\text { compared with TIO (mean difference } 61 \mathrm{~mL} ; \mathrm{p}<0.001 \text { ) } \\
\text { GB/FF/BDP was non-inferior to FF/BDP }+\mathrm{TIO} \text { in terms } \\
\text { of lung function (adjusted mean difference }-3 \mathrm{~mL} \text { ) } \\
\text { GB/FF/BDP significantly improved SGRO total score } \\
\text { compared with TIO at all time-points except week } 26 \\
\text { GB/FF/BDP and FF/BDP + TIO resulted in similar rates } \\
\text { of moderate or severe exacerbations (rate ratio } 1.01 \text {; } \\
95 \% \text { CI } 0.85 \text { to } 1.21 \text { ) and provided a similar mean } \\
\text { change from baseline in SGRO total score at all } \\
\text { time-points except weeks } 26 \text { and } 52\end{array}$ \\
\hline $\begin{array}{l}\text { Papi et al. } \\
\text { (TRIBUTE) }^{44}\end{array}$ & $\begin{array}{l}1532 \text { patients with a } \\
\text { post-bronchodilator } \\
\mathrm{FEV}_{1}<50 \%, \geq 1 \\
\text { moderate-to-severe } \\
\text { COPD exacerbation } \\
\text { in the previous } \\
12 \text { months, CAT total } \\
\text { score } \geq 10 \text { and, who } \\
\text { had used LABA/ICS, } \\
\text { LAMA/ICS, LAMA/ } \\
\text { LABA, or LAMA } \\
\text { monotherapy, but } \\
\text { not triple therapy, for } \\
\text { at least } 2 \text { months } \\
\text { before screening }\end{array}$ & $\begin{array}{l}\text { Multicentre, } \\
\text { randomised, } \\
\text { parallel-group, } \\
\text { double-blind, } \\
\text { double-dummy } \\
\text { study over } \\
52 \text { weeks }\end{array}$ & $\begin{array}{l}\text { GB/FF/BDP } \\
\text { 25/12/200 } \mu \mathrm{g} \\
\text { twice daily } \\
\text { GB/IND 43/85 } \mu \mathrm{g} \\
\text { once daily }\end{array}$ & 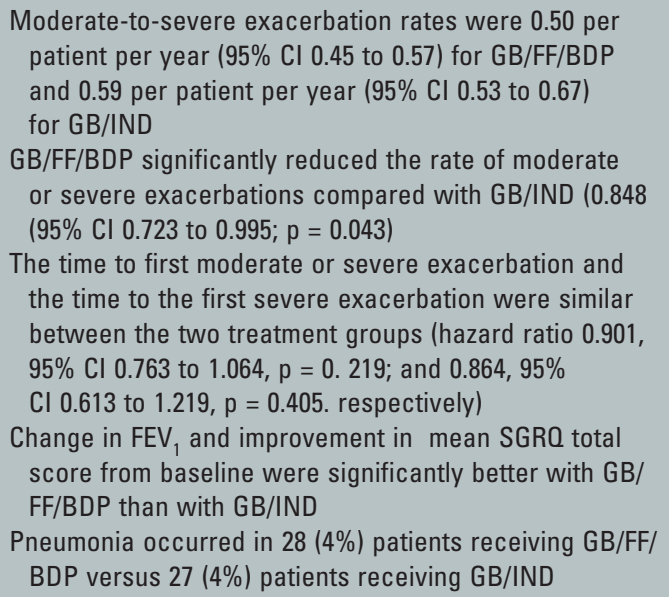 \\
\hline
\end{tabular}


TABLE 3. Trials with triple therapy administered in a single inhaler (continuation)

\begin{tabular}{|c|c|c|c|c|}
\hline Study & Patients & Study design & Therapy & Key findings \\
\hline \multicolumn{5}{|c|}{ Umeclidinium/vilanterol/fluticasone furoate } \\
\hline Siler et al. ${ }^{46}$ & $\begin{array}{l}727 \text { patients with a } \\
\text { post-bronchodilator } \\
\mathrm{FEV}_{1} \leq 0.70 \text { and a } \\
\mathrm{mMRC} \text { dyspnea } \\
\text { scale score } \geq 2\end{array}$ & $\begin{array}{l}\text { Two replicate, } \\
\text { multicentre, } \\
\text { randomised, } \\
\text { double-blind, } \\
\text { placebo-controlled } \\
\text { parallel-group } \\
\text { studies over } \\
12 \text { weeks }\end{array}$ & $\begin{array}{l}\text { VI/FLF 25/100 } \mu \mathrm{g} \\
+ \text { UMEC } 62.5 \mu \mathrm{g} \\
\text { VI/FLF } 25 / 100 \mu \mathrm{g} \\
+ \text { UMEC } 125 \mu \mathrm{g} \\
\text { VI/FLF 25/100 } \mu \mathrm{g}\end{array}$ & 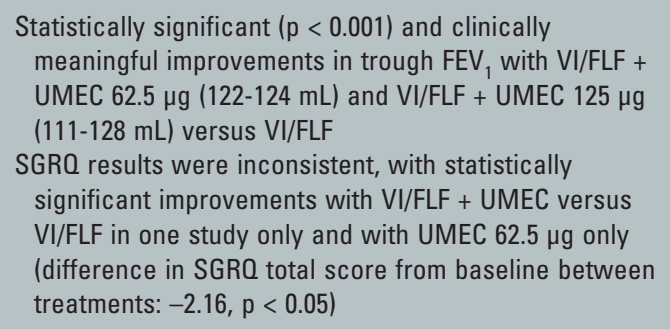 \\
\hline $\begin{array}{l}\text { Lips et al. } \\
\text { (FULFIL) }^{47}\end{array}$ & $\begin{array}{l}1810 \text { patients defined } \\
\text { as GOLD D (FEV } \\
<50 \% \text { and CAT } \geq 10, \\
\text { or patients with FEV } \\
\geq 50-<80 \% \text { and CAT } \\
\geq 10 \text {, and either } \\
\geq 2 \text { moderate exacer- } \\
\text { bations in the past } \\
\text { year or } \geq 1 \text { severe } \\
\text { exacerbation in the } \\
\text { past year), who had } \\
\text { used daily mainte- } \\
\text { nance therapy for at } \\
\text { least } 3 \text { months before } \\
\text { screening }\end{array}$ & $\begin{array}{l}\text { Multicentre, } \\
\text { randomised, } \\
\text { double-blind, } \\
\text { double-dummy } \\
\text { study over } \\
24 \text { weeks }\end{array}$ & $\begin{array}{l}\text { UMEC/VI/FLF } \\
62.5 / 25 / 100 \mu \mathrm{g} \\
\text { once daily } \\
\text { FF/BUD } 12 / 400 \mu \mathrm{g} \\
\text { twice daily }\end{array}$ & $\begin{array}{l}\text { At Week } 24 \text {, triple therapy significantly improved trough } \\
\text { FEV }{ }_{1} \text { (between- treatment difference: } 171 \mathrm{~mL} ; \mathrm{p}<0.001 \text { ) } \\
\text { and } \mathrm{SGRO} \text { total score (between-treatment difference: } \\
-2.2 \text { units; } p<0.001 \text { ) compared with FF/BUD } \\
\text { At Week } 52 \text {, triple therapy significantly improved trough } \\
\mathrm{FEV}_{1} \text { compared with FF/BUD (between treatment } \\
\text { difference: } 179 \mathrm{~mL} ; \mathrm{p}<0.001 \text { ) } \\
\text { No significant difference in SGR0 total score at week } 52 \\
\text { (between-treatment difference: }-2.7 \text { units) } \\
\text { Triple significantly reduced the rate of moderate or } \\
\text { severe exacerbations (up to } 24 \text { weeks and } 52 \text { weeks) } \\
\text { compared with } \mathrm{FF/BUD} \mathrm{(35 \%} \mathrm{reduction} \mathrm{in} \mathrm{rate;} \\
\mathrm{p}=0.002 \text { and } 44 \% \text { reduction in rate } \mathrm{p}=0.006 \text {, } \\
\text { respectively) }\end{array}$ \\
\hline $\begin{array}{c}\text { Bremner } \\
\text { et al. }^{49}\end{array}$ & $\begin{array}{l}1311 \text { patients defined } \\
\text { as GOLD D (FEV } \\
<50 \% \text { and CAT } \geq 10 \text {, } \\
\text { or patients with } \mathrm{FEV}, \\
\geq 50-<80 \% \text { and } \mathrm{CAT} \\
\geq 10 \text {, and either } \\
\geq 2 \text { moderate } \\
\text { exacerbations in the } \\
\text { past year or } \\
\geq 1 \text { severe exacerba- } \\
\text { tion in the past year) }\end{array}$ & $\begin{array}{l}\text { Multicentre, } \\
\text { randomised, } \\
\text { double-blind, } \\
\text { parallel group, } \\
\text { multicenter } \\
\text { non-inferiority } \\
\text { study over } 2 \text { weeks }\end{array}$ & $\begin{array}{l}\text { UMEC/VI/FLF } \\
62.5 / 25 / 100 \mu \mathrm{g} \\
\text { once daily } \\
\text { VI/FLF } 25 / 100 \mu \mathrm{g} \\
\text { + UMEC } 62.5 \mu \mathrm{g} \\
\text { once daily }\end{array}$ & $\begin{array}{l}\text { Mean change from baseline in trough } \mathrm{FEV}_{1} \text { was } 113 \mathrm{~mL} \\
\text { (95\% CI } 91 \text { to } 135 \text { ) for UMEC/VI/FLF and } 95 \mathrm{~mL}(95 \% \mathrm{CI} \\
72 \text { to } 117 \text { ) for VI/FLF + UMEC } \\
\text { The proportion of responders based on SGRQ Total } \\
\text { score was } 50 \% \text { (UMEC/VI/FLF) and } 51 \% \text { (VI/ } \\
\text { FLF + UMEC); the proportion of responders based on } \\
\text { the TDI focal score was similar ( } 56 \% \text { both groups) } \\
\text { The proportion of patients experienced a moderate/ } \\
\text { severe exacerbation in the UMEC/VI/FLF ( } 24 \% \text { ) and VI/ } \\
\text { FLF + UMEC ( } 27 \% \text { ) was similar } \\
\text { The incidence of pneumonia (UMEC/VI/FLF, 3\%; VI/ } \\
\text { FLF + UMEC, 4\%) was similar }\end{array}$ \\
\hline $\begin{array}{l}\text { Lipson et al. } \\
(\text { (IMPACT) }\end{array}$ & $\begin{array}{l}10,355 \text { patients with } \\
\mathrm{FEV}_{1}<50 \% \text { and } \mathrm{CAT} \\
\geq 10 \text { and } \geq 1 \text { moder- } \\
\text { ate or severe } \\
\text { exacerbation in the } \\
\text { previous year, or } \\
\text { patients with } \mathrm{FEV} \\
\geq 50-<80 \% \text { and CAT } \\
\geq 10 \text {, and } \geq 2 \text { moder- } \\
\text { ate exacerbations in } \\
\text { the past year or } \\
\geq 1 \text { severe exacerba- } \\
\text { tion in the previous } \\
\text { year }\end{array}$ & $\begin{array}{l}\text { Multicentre, } \\
\text { randomised, } \\
\text { double-blind, } \\
\text { parallel-group, trial } \\
\text { over } 52 \text { weeks }\end{array}$ & $\begin{array}{l}\text { UMEC/VI/FLF } \\
62.5 / 25 / 100 \mu \mathrm{g} \\
\text { once daily } \\
\text { UMEC/VI } 62.5 / 25 \mu \mathrm{g} \\
\text { once daily } \\
\text { VI/FLF } 25 / 100 \mu \mathrm{g} \\
\text { once daily }\end{array}$ & $\begin{array}{l}\text { Moderate-to-severe exacerbation rates were } 0.91 \text { per } \\
\text { patient per year for UMEC/VI/FLF, } 1.07 \text { per patient per year } \\
\text { for VI/FLF (rate ratio with triple therapy, } 0.85 ; 95 \% \text { CI } 0.80 \\
\text { to } 0.90 ; 15 \% \text { difference; } p<0.001 \text { ), and } 1.21 \text { per patient } \\
\text { per year for UMEC/VI (rate ratio with triple therapy, } 0.75 \text {; } \\
95 \% \mathrm{CI} 0.70 \text { to } 0.81 ; 25 \% \text { difference; } p<0.001 \text { ) } \\
\text { The annual rate of moderate or severe exacerbations was } \\
\text { lower with triple therapy than with either dual-thera- } \\
\text { py combination, regardless of eosinophil level } \\
\text { The annual rate of severe exacerbations was not significant- } \\
\text { ly lower with UMEC/VI/FLF than with VI/FLF but was } \\
\text { significantly lower with triple therapy than with UMEC/VI } \\
\text { Change in FEV }{ }_{1} \text { and improvement in mean SGR0 total } \\
\text { score from baseline were significantly better with } \\
\text { UMEC/VI/FLF than with either dual-therapy combination } \\
\text { The risk of clinician-diagnosed pneumonia was } \\
\text { significantly higher with UMEC/VI/FLF than with UMEC/ } \\
\text { VI, as assessed in a time-to-first event analysis (hazard } \\
\text { ratio, } 1.53 ; 95 \% \mathrm{Cl}, 1.22 \text { to } 1.92 ; \mathrm{p}<0.001 \text { ) but not with } \\
\text { VI/FLF (hazard ratio, } 1.02 ; 95 \% \mathrm{Cl}, 0.87 \text { to } 1.19 ; \mathrm{p}=0.85 \text { ) }\end{array}$ \\
\hline
\end{tabular}


TABLE 3. Trials with triple therapy administered in a single inhaler (continuation)

\begin{tabular}{|c|c|c|c|c|}
\hline Study & Patients & Study design & Therapy & Key findings \\
\hline \multicolumn{5}{|c|}{ Glycopyrronium bromide/formoterol fumarate/budesonide } \\
\hline $\begin{array}{l}\text { Darken } \\
\text { et al. }{ }^{52}\end{array}$ & 84 healthy volunteers & $\begin{array}{l}\text { Randomised, Phase I, } \\
\text { single-dose, } \\
\text { six-treatment, } \\
\text { four-period, } \\
\text { crossover study }\end{array}$ & $\begin{array}{l}\text { GB/FF/BUD } \\
(14.4 / 10 / 320 \mu \mathrm{g} \\
\text { (equivalent to } \\
\text { GB/FF/BUD } \\
18 / 9.6 / 320 \mu \mathrm{g}) \\
14.4 / 10 / 160 \mu \mathrm{g} \\
\text { and } 14.4 / 10 / 80 \\
\text { FF/BUD } 9 / 320 \mu \mathrm{g} \\
\text { and } 9 / 160 \mu \mathrm{g} \\
\text { GB/FF } 14.4 / 10 \mu \mathrm{g}\end{array}$ & $\begin{array}{l}\mathrm{SGB} / \mathrm{FF} / \mathrm{BUD} 14.4 / 10 / 320 \mu \mathrm{g} \text { was bioequivalent to FF/BUD } \\
320 / 9 \mu \mathrm{g} \text { for BUD for } \mathrm{C}_{\text {max }^{\prime}} \mathrm{AUC}_{0-12} \text { and } \mathrm{AUC}_{0-\mathrm{t}} \\
\text { Dose proportionality was observed for the BUD } \\
\text { component between GB/FF/BUD } 14.4 / 10 / 80 \mu \mathrm{g} \text { and } \\
\mathrm{GB} / \mathrm{FF} / \mathrm{BUD} 14.4 / 10 / 160 \mu \mathrm{g} \text {, and between GB/FF/BUD } \\
14.4 / 10 / 160 \mu \mathrm{g} \text { and GB/FF/BUD 14.4/10/320 Systemic } \\
\text { exposure to GB and FF after GB/FF/BUD } 14.4 / 10 / 320 \mu \mathrm{g} \\
\text { treatment was similar to GB/FF/BUD 14.4/10/320 } \\
\text { The rate of adverse events was 3.7-17.9\% across } \\
\text { treatments without any serious adverse events }\end{array}$ \\
\hline
\end{tabular}

$\mathrm{AUC}_{0-12}$ : area under the plasma concentration-time curve from 0 to $12 \mathrm{~h} ; \mathrm{AUC}_{0-\mathrm{t}}$ : area under the plasma concentration-time curve up to the last measurable concentration; BDP: beclometasone dipropionate; BUD: budesonide; $C A T$ : COPD assessment test; $\mathrm{Cl}$ : confidence interval; $\mathrm{C}_{\text {max }}$ : maximum plasma concentration; $\mathrm{COPD}$ : chronic obstructive pulmonary disease; $\mathrm{FEV}_{1}$ : forced expiratory volume in one second; FF: formoterol fumarate; FLF: fluticasone furoate; GB: glycopyrronium bromide; mMRC: modified Medical Research Council; SGRQ: St George's Respiratory Questionnaire; TDI: Transition Dyspnoea Index; TIO: tiotropium; UMEC: umeclidinium; VI: vilanterol.

respectively. It has an extrafine formulation and is administered twice-daily.

An initial Phase II study (Triple therapy prevention of Recurrent Intracerebral Disease EveNts Trial [TRIDENT]) showed the potential benefits on lung function of stepping-up to triple therapy through the addition of GB for patients already on FF/BDP ${ }^{41}$. Afterwards, three pivotal Phase III studies (Single inhaler triple therapy versus inhaled corticosteroid plus long-acting $\beta_{2}$-agonist therapy for COPD [TRILOGY] ${ }^{42}$, Single inhaler extrafine triple therapy versus long-acting muscarinic antagonist therapy for COPD [TRINITY] ${ }^{43}$ and Extrafine inhaled triple therapy versus dual bronchodilator therapy in COPD [TRIBUTE] ${ }^{44}$ ) have provided precious information on the therapeutic value of this triple combination.

The TRILOGY study compared GB/FF/BDP with FF/BDP in COPD patients with severe or very severe airflow limitation, symptoms, and an exacerbation history ${ }^{42}$. After 26-week treatment, triple therapy significantly improved pre-dose $\mathrm{FEV}_{1}(+81 \mathrm{~mL})$ and two-hour postdose $\mathrm{FEV}_{1}(+117 \mathrm{~mL})$, but there were no significant improvements in TDI. The adjusted annual rate of moderate-to-severe exacerbations was 0.41 for GB/FF/BDP and 0.53 for FF/BDP. A rate ratio of 0.77 indicated a $23 \%$ reduction with $\mathrm{GB} / \mathrm{FF} / \mathrm{BDP}$.

In the TRINITY study, GB/FF/BDP was compared with FF/BDP + tiotropium (open triple) and with tiotropium alone in a 52-week study ${ }^{43}$. The inclusion criteria were very similar to those of TRILOGY. Triple therapy improved pre-dose $\mathrm{FEV}_{1}(+61 \mathrm{~mL})$ compared with tiotropium, but there was no difference between fixed and ex-temporary triple combination $(-3 \mathrm{~mL})$. The adjusted annual rate of moderate-to-severe exacerbations was 0.46 for GB/FF/BDP and 0.57 for tiotropium, with a rate ratio of 0.80 , indicating a $20 \%$ reduction with GB/FF/BDP. No difference was observed between fixed and ex-temporary triple combination either in adjusted annual rate of moderate-to-severe exacerbations ( 0.46 versus 0.45$)$. 
In the TRIBUTE study, GB/FF/BDP was compared with GB/IND in terms of the rate of moderate-to-severe AECOPDs over 52 weeks of treatment ${ }^{44}$. Moderate-to-severe exacerbation rates were 0.50 per patient per year for GB/FF/ $\mathrm{BDP}$ and 0.59 per patient per year for GB/IND, with a rate ratio of 0.85 , indicating a $15 \%$ reduction with BDP/FF/GB. Change in $\mathrm{FEV}_{1}$ and improvement in mean SGRQ total score from baseline were significantly better with $\mathrm{GB} / \mathrm{FF} /$ BDP than with GB/IND.

\section{b. Umeclidinium/vilanterol/ fluticasone furoate combination}

Umeclidinium/vilanterol/fluticasone furoate is another triple FDC under clinical development. In a Phase I study, systemic exposure to all three components of this FDC following single-dose delivery in healthy volunteers was similar to that seen with VI/FLF and UMEC/VI ${ }^{45}$.

Two RCTs demonstrated that UMEC $(62.5 \mu \mathrm{g}$ and $125 \mu \mathrm{g}+\mathrm{VI} / \mathrm{FLF}(25 / 100 \mu \mathrm{g})$ provides statistically significant and clinically meaningful improvements in lung function compared with placebo + VI/FLF 25/100 $\mu \mathrm{g}$ in COPD patients (difference in trough $\mathrm{FEV}_{1}$ versus placebo + VI/FLF at day 85: $+124 \mathrm{~mL}$ with UMEC $62.5 \mu \mathrm{g}$ + VI/FLF, and +122 mL with UMEC $125 \mu \mathrm{g}+$ $\mathrm{VI} / \mathrm{FF})^{46}$. However, statistically significant improvements in HRQoL with UMEC+VI/FLF versus placebo+VI/FLF were reported in one study only.

The Lung function and quality of life assessment in COPD with closed triple therapy (FULFIL) trial compared 24 weeks of UMEC/VI/FLF 62.5/25/100 $\mu \mathrm{g}$ with $\mathrm{FF} /$ budesonide (BUD)
12/400 $\mu \mathrm{g}$ in GOLD D patients ${ }^{47}$. At week 24, the difference between UMEC/VI/FLF and $\mathrm{FF} / \mathrm{BUD}$ in trough $\mathrm{FEV}_{1}(171 \mathrm{~mL})$ was statistically significant. The mean annualised rate of moderate/severe exacerbations was 0.22 and 0.34 for UMEC/VI/FF and FF/BUD, respectively, indicating a significant $35 \%$ reduction in the annualised rate with triple therapy compared with LABA/ICS. Umeclidinium/vilanterol/ fluticasone furoate also improved symptoms and HRQoL compared with twice-daily FF/ $\mathrm{BUD}^{48}$.

A large RCT has evaluated the non-inferiority of single-inhaler UMEC/VI/FLF versus VI/FLF + UMEC using two inhalers and has shown that single-inhaler triple therapy with UMEC/ VI/FLF offers similar efficacy, HRQoL, and safety benefits as the same triple therapy administered using two inhalers ${ }^{49}$.

The Informing the Pathway of COPD Treatment (IMPACT) trial has been a Phase III, randomised, double-blind, three-arm, parallel-group, global multicentre study comparing the rate of moderate and severe exacerbations between UMEC/VI/FLF and VI/FLF or UMEC/ VI in 10,355 patients with COPD over a 52-week treatment period ${ }^{50}$. Patients had to have either a $\mathrm{FEV}_{1}$ less than $50 \%$ of the predicted normal value and a history of at least one moderate or severe exacerbation in the previous year, or an $\mathrm{FEV}_{1}$ of 50 to $80 \%$ of the predicted normal value and at least two moderate exacerbations or one severe exacerbation in the previous year. There was a significant reduction in moderate-to-severe exacerbation rate with triple therapy $(-15 \%$ versus VI/FLF and $-25 \%$ versus $\mathrm{UMEC} / \mathrm{VI})$. The rate of moderate or severe exacerbations in the UMEC/VI/FLF group was 0.91 per year, as compared with 1.07 per year in 
the VI/FLF group (rate ratio, 0.85) and 1.21 per year in the UMEC/VI group (rate ratio, 0.75). Triple therapy significantly reduced also the annual rate of severe exacerbations compared to UMEC/VI (rate ratio, 0.66; 34\% difference), but not to VI/FLF (rate ratio, $0.87 ; 13 \%$ difference).

Umeclidinium/vilanterol/fluticasone furoate was more effective than the other two treatments in improving the trough $\mathrm{FEV}_{1}$ at week $52(+97 \mathrm{~mL}$ versus $\mathrm{VI} / \mathrm{FF}$, and $+54 \mathrm{~mL}$ versus UMEC/VI). It was also significantly better than the other two treatments with respect to the impact on SGRQ total score and in the percentage of patients who had a response as defined by a decrease in the SGRQ total score of at least 4 points. Furthermore, in a subset of 5058 patients, the percentage of patients who had a response as defined by an increase in the TDI of at least one unit was higher with triple therapy than with either dual therapy. The risk of clinician-diagnosed pneumonia was significantly higher with UMEC/ VI/FLF than UMEC/VI as assessed in a timeto-first-event analysis (hazard ratio [HR] 1.53), but not than VI/FLF (HR 1.02).

\section{c. Glycopyrronium bromide/formoterol fumarate/ budesonide combination}

Glycopyrronium bromide/budesonide/formoterol fumarate FDC is the third triple therapy under clinical development. It uses Aerosphere Delivery Technology (ADT), which provides a stable, uniform, and easily dispersed MDI suspension formulation when combined with one or multiple types of drug crystals $^{51}$. A Phase I trial documented no drug-drug interaction when comparing pharmacokinetics of GB/FF/BUD 14.4/9.6/320 $\mu \mathrm{g}$ to $\mathrm{GB}^{52}$. Systemic exposure to BUD following administration of GB/FF/BUD was slightly higher but bioequivalent to FF/BUD pMDI 9/320 $\mu$ g. No pharmacokinetic drug-drug interactions were observed when BUD was added to GB and FF.

ATHENA is a Phase III clinical trial programme for GB/FF/BUD FDC, which will include more than 15,500 patients globally across 11 trials. Top-line results from the Phase III Study to Assess the Efficacy and Safety of PT010, PT003, and PT009 Compared With Symbicort ${ }^{\circledR}$ Turbuhaler ${ }^{\circledR}$ in Subjects with Moderate-to-VerySevere COPD (KRONOS) trial have been announced ${ }^{53}$. The latter study is a randomised, double-blind, parallel-group, 24-week, chronic-dosing, multi-centre trial to assess the efficacy and safety of GB/FF/BUD FDC. The trial compared GB/FF/BUD FDC to GB/FF 14.4/9.6 $\mu \mathrm{g}$ using ADT, FF/BUD 12/400 $\mu \mathrm{g}$ Turbuhaler and FF/BUD 9.6/320 $\mu \mathrm{g}$ using ADT. Triple combination demonstrated a statistically significant improvement compared with dual combination therapies in six out of seven lung function primary endpoints based on $\mathrm{FEV}_{1}$ assessments in patients with moderate-to-very-severe COPD. In total, eight of the nine primary endpoints in the KRONOS trial were met, including two non-inferiority endpoints to qualify FF/BUD 9.6/320 $\mu \mathrm{g}$ delivered using ADT.

The Study to Assess the Efficacy and Safety of PT009 (budesonide and formoterol fumarate MDI) Compared to PT005 (formoterol fumarate MDI) on COPD Exacerbations Over a 52-Week Period in Subjects With Moderate-to-Very-Severe COPD (SOPHOS) assesses 
the efficacy and safety of GB/FF/BUD FDC compared to FF/BUD 9.6/320 $\mu \mathrm{g}$ and FF $9.6 \mu \mathrm{g}$ (ClinicalTrials.gov Identifier: 02727660). The Study to Assess the Efficacy and Safety of PT010 Relative to PT003 (glycopyrronium and formoterol fumarate MDI) and PT009 in Subjects With Moderate-to-Very-Severe COPD (ETHOS) is a randomised, double-blind, multicentre, parallel-group study that is assessing the efficacy and safety of GB/FF/BUD FDC relative to GB/FF 14.4/9.6 $\mathrm{\mu g}$ and FF/BUD 9.6/320 $\mu \mathrm{g}$ on AECOPDs over a 52-week treatment period in approximately 8000 patients (ClinicalTrials.gov Identifier: NCT02465567).

\section{WHAT DOES NEW EVIDENCE TELL US?}

Nowadays, we have evidence that LAMA/ LABA FDCs may be more effective than LABA/ ICS in reducing the risk of exacerbations ${ }^{54}$ and this finding raises the fundamental question of whether the potential benefit gained by adding ICS to the dual-bronchodilator therapy actually overcomes the risk of adverse effects and the increased cost of triple therapy ${ }^{30}$.

The TRIBUTE study demonstrated a $15 \%$ reduction in exacerbations with triple therapy compared with dual bronchodilation ${ }^{44}$. However, TRIBUTE, as well as TRILOGY ${ }^{42}$ and TRINITY ${ }^{43}$ studies, was not focused on frequent exacerbators and, consequently, the annual rate of exacerbations was too low to evaluate the true value of this reduction. Therefore, it is difficult to draw firm conclusions on this finding. Likely, it would be preferable to calculate how many exacerbations requiring medical intervention would be prevented for every 100 patients treated for one year with GB/FF/BDP versus GB/IND therapy. In any case, the rates of moderate and severe exacerbations analysed separately were not significantly different between GB/FF/BDP and GB/IND. Also the time to first moderate or severe exacerbation was similar between the two treatment groups. All these findings suggest that either the triple therapy is actually not more effective than double bronchodilation in reducing the risk of exacerbations, or/and the study has been not sufficiently well designed. Also the results of the FULFIL study are not very useful because it was a 24-week trial, but, due to seasonal variation, an evaluation of exacerbation frequency requires a period of $\geq 1$ year and, furthermore, the timing of the study treatment may prove important (e.g. capturing winter cold season in the majority of patients) ${ }^{55}$.

The 2018 GOLD strategy suggests for patients with GOLD D escalation from dual bronchodilation to LAMA/LABA/ICS, and when LABA/ ICS therapy does not positively impact exacerbations/symptoms, a LAMA can be added ${ }^{1}$. Regrettably, there is still no solid evidence of a real clinical advantage when performing such an escalation. Suissa and Drazen ${ }^{56}$, while editorialising the IMPACT study data, highlighted that although this trial has addressed the possibility of a step-up approach from a dual long-acting bronchodilator regimen to triple therapy, the results of the study were probably artificially inflated because the majority of the enrolled patients were already treated with ICSs and some of them had a history of asthma. For this reason, they think that the IMPACT trial falls short of providing the anticipated strong evidence to better understand the potential for stepping-up to single inhaler triple therapy in clinical practice. Umeclidinium/vilanterol/fluticasone furoate 
and VI/FLF also showed a signal toward lower all-cause mortality during treatment than $\mathrm{UMEC} / \mathrm{VI}^{50}$. However, we do not believe that it is an outcome endowed with consistency, and not only because it contradicts the results of the Study to Understand Mortality and Morbidity in COPD (SUMMIT) study that was powered to evaluate all-cause mortality and did not show a significant effect for VI/FLF ${ }^{57}$, but also, and mainly because death from any cause during treatment was not a pre-specified primary and secondary outcome. This means that the study was not appropriately powered to assess effects on mortality.

At this point in time, we are waiting for the results of the ETHOS study, mainly because of the number of patients involved. However, we must highlight that the step-up approach from dual bronchodilation to triple therapy takes no account of the critical differences in COPD exacerbations (they differ in aetiology, severity, and biological substrate), and thus it is not designed on the patient's specific needs to be treated ${ }^{58}$.

In any case, we fully agree that the available evidence does support the current recommendation of triple therapy for GOLD D patients, but it only suggests triple therapy is effective in GOLD B patients (i.e. highly symptomatic but at low risk of exacerbations) $)^{59}$. Therefore, the current GOLD strategy recommendations should be revisited and studies with triple therapy in GOLD B patients should be conducted with the aim of testing its effect on hospitalisations and survival ${ }^{59}$. However, Suissa and Drazen ${ }^{56}$ have invoked caution in using the single-inhaler triple therapy in treating COPD because any potential benefit could be lost and potential undue harm induced if triple therapy is expanded to GOLD A, B, and $\mathrm{C}$ patients.

Now we must establish whether and when addition of an ICS to the LAMA/LABA combination provides real additional clinical value, regardless of a preventive effect on exacerbations, and determine what kind of benefit it is, or whether LAMA/LABA combination therapy is preferred over triple therapy also because of the cost differences of the two treatments in real-life. It has been suggested that baseline blood eosinophil levels may represent an informative marker for exacerbation reduction with LABA/ICS in patients with COPD and a history of moderate-to-severe exacerbations ${ }^{60}$. Nonetheless, prospective analyses of data from the Effect of Indacaterol Glycopyronium versus Fluticasone Salmeterol on COPD Exacerbations (FLAME) trial indicate that dual bronchodilation provides superior or similar benefits over LABA/ICS regardless of blood eosinophil levels in patients with $\mathrm{COPD}^{61}$. In the TRIBUTE trial, the relative effect of GB/FF/ BDP versus GB/IND on moderate-to-severe exacerbations was greater in patients with eosinophils $>2 \%$, but the effect of the two treatments was not significantly different when an eosinophil threshold of 200 cells per $\mu \mathrm{L}$ was used $^{44}$. However, in the IMPACT study, the annual rate of moderate-to-severe exacerbations was lower with triple therapy regardless of eosinophil level ${ }^{50}$. Therefore, it is obvious that at the present time blood eosinophil counts cannot be recommended as an unquestionable biomarker for the management of individual patients with $\mathrm{COPD}^{62}$.

In any case, we agree that it can be difficult to discern whether an individual who continues to experience exacerbations following the 
addition of an ICS would have experienced a similar number or more of these events without this addition ${ }^{63}$.

Also the evaluation of possible risk of adverse events is central to the choice of therapy. The overall incidence of pneumonia in the IMPACT study was $50 \%$ higher in patients treated with UMEC/VI/FLF than in the UMEC/VI group ${ }^{50}$, whereas in the TRIBUTE trial the addition of BDP did not increase the risk of pneumonia ${ }^{44}$.

\section{CONCLUSIONS}

Although the available information has greatly increased in recent years, there is still no solid evidence to state whether and when addition of an ICS to the LAMA/LABA combination provides additional clinical value. Therefore, a strong recommendation cannot be generated as yet. However, it is likely that the fundamental question in the next paradigm for the treatment of COPD will no longer be whether and/or when it is appropriate to switch patients with COPD from a LABA/ICS regimen to a LAMA/LABA one, but rather in which patients and when we can add an ICS to the dual bronchodilation.

We strongly believe that maximising the treatment in patients with a degree of clinical instability by including an ICS in the therapeutic regimen is useful to control the disease but may not be needed during periods of clinical stability. However, it is always better to avoid a therapeutic step-up progression when it is not needed rather than being forced subsequently into a step-down approach in which the outcome is always unpredictable ${ }^{64}$.

\section{FUNDING}

This review was not funded.

\section{CONFLICTS OF INTEREST}

Dr. Cazzola has participated as a speaker and advisor in scientific meetings and course under the sponsorship of Almirall, AstraZeneca, Biofuturam Boehringer Ingelheim, Chiesi, GlaxoSmithKline, Menarini Group, Lallemand, Mundipharma, Novartis, Pfizer, Recipharm, and Zambon. He is or has been a consultant to ABC Farmaceutici, Chiesi, Lallemand, Novartis, Verona Pharma, and Zambon. Dr. Rogliani has participated as a speaker and advisor in scientific meetings and courses under the sponsorship of Almirall, AstraZeneca, Biofutura, Boehringer Ingelheim, Chiesi, GlaxoSmithKline, Menarini Group, Mundipharma, and Novartis. Dr. Matera has participated as a speaker and advisor in scientific meetings and courses under the sponsorship of Almirall, AstraZeneca, Boehringer Ingelheim, Chiesi, GlaxoSmithKline, Novartis, and Zambon. She is or has been a consultant to ABC Farmaceutici, and Chiesi.

\section{REFERENCES}

1. Global Initiative for Chronic Obstructive Lung Disease. Global strategy for diagnosis, management, and prevention of COPD: 2018 report. http://goldcopd.org/wp-content/uploads/2017/11/GOLD-2018-v6.0-FINAL-revised20-Nov_WMS.pdf. Accessed March 5, 2018.

2. Calzetta L, Rogliani P, Matera MG, Cazzola M. A systematic review with meta-analysis of dual bronchodilation with LAMA/LABA for the treatment of stable COPD. Chest. 2016;149:1181-96.

3. Horita N, Goto A, Shibata Y et al. Long-acting muscarinic antagonist (LAMA) plus long-acting beta-agonist (LABA) versus LABA plus inhaled corticosteroid (ICS) for stable chronic obstructive pulmonary disease (COPD). Cochrane Database Syst Rev 2017;2:CD012066.

4. Simeone JC, Luthra R, Kaila S et al. Initiation of triple therapy maintenance treatment among patients with COPD in the US. Int J Chron Obstruct Pulmon Dis. 2016;12:73-83. 
5. James GD, Donaldson GC, Wedzicha JA, Nazareth I. Trends in management and outcomes of COPD patients in primary care, 2000-2009: a retrospective cohort study. NPJ Prim Care Respir Med. 2014;24:14015.

6. Brusselle G, Price D, Gruffydd-Jones K et al. The inevitable drift to triple therapy in COPD: an analysis of prescribing pathways in the UK. Int J Chron Obstruct Pulmon Dis. 2015;10:2207-17.

7. Di Marco F, Santus P, Terraneo S et al. Characteristics of newly diagnosed COPD patients treated with triple inhaled therapy by general practitioners: a real world Italian study. NPJ Prim Care Respir Med. 2017;27:51.

8. Miyazaki M, Nakamura $H$, Takahashi $S$ et al. The reasons for triple therapy in stable COPD patients in Japanese clinical practice. Int J Chron Obstruct Pulmon Dis. 2015;10:1053-9.

9. Mapel D, Laliberté F, Roberts $\mathrm{MH}$ et al. A retrospective study to assess clinical characteristics and time to initiation of open-triple therapy among patients with chronic obstructive pulmonary disease, newly established on long-acting mono- or combination therapy. Int J Chron Obstruct Pulmon Dis. 2017;12:1825-36.

10. Sundh J, Åberg J, Hasselgren $\mathrm{M}$ et al. Factors influencing pharmacological treatment in COPD: a comparison of 2005 and 2014. Eur Clin Respir J. 2017; 4:1409060.

11. Corrado A, Rossi A. How far is real life from COPD therapy guidelines? An Italian observational study. Respir Med. 2012;106:989-97.

12. Vestbo J, Vogelmeier C, Small M, Higgins V. Understanding the GOLD 2011 Strategy as applied to a real-world COPD population. Respir Med. 2014;108: 729-36.

13. Cazzola M, Matera MG. Triple combinations in chronic obstructive pulmonary disease - is three better than two? Expert Opin Pharmacother. 2014;15:2475-8.

14. Karner C, Cates CJ. Combination inhaled steroid and long-acting beta ${ }_{2}$-agonist in addition to tiotropium versus tiotropium or combination alone for chronic obstructive pulmonary disease. Cochrane Database Syst Rev. 2011; 3:CD008532.

15. Cazzola M, Andò F, Santus P et al. A pilot study to assess the effects of combining fluticasone propionate/salmeterol and tiotropium on the airflow obstruction of patients with severe-to-very severe COPD. Pulm Pharmacol Ther. 2007;20:556-61.

16. Welte T, Miravitlles M, Hernandez P et al. Efficacy and tolerability of budesonide/formoterol added to tiotropium in patients with chronic obstructive pulmonary disease. Am J Respir Crit Care Med. 2009;180:741-50.

17. Aaron SD, Vandemheen KL, Fergusson D et al. Tiotropium in combination with placebo, salmeterol, or fluticasone-salmeterol for treatment of chronic obstructive pulmonary disease: a randomized trial. Ann Intern Med. 2007;146:545-55.

18. Rojas-Reyes MX, García Morales OM, Dennis RJ, Karner C. Combination inhaled steroid and long-acting beta ${ }_{2}$-agonist in addition to tiotropium versus tiotropium or combination alone for chronic obstructive pulmonary disease. Cochrane Database Syst Rev. 2016;CD008532.

19. Hoshino M, Ohtawa J. Effects of adding salmeterol/fluticasone propionate to tiotropium on airway dimensions in patients with chronic obstructive pulmonary disease. Respirology. 2011;16:95-101.

20. Hanania NA, Crater GD, Morris AN et al. Benefits of adding fluticasone propionate/salmeterol to tiotropium in moderate to severe COPD. Respir Med. 2012;106:91-101.

21. Jung KS, Park HY, Park SY et al. Comparison of tiotropium plus fluticasone propionate/salmeterol with tiotropium in COPD: a randomized controlled study. Respir Med. 2012;106:382-9.

22. Ferroni E, Belleudi V, Cascini $S$ et al. Role of tiotropium in reducing exacerbations of chronic obstructive pulmonary disease when combined with long-acting $\beta_{2}$-agonists and inhaled corticosteroids: The OUTPUL study. J Clin Pharmacol. 2016;56:1423-32.

23. Short PM, Williamson PA, Elder DH et al. The impact of tiotropium on mortality and exacerbations when added to inhaled corticosteroids and long-acting $\beta$-agonist therapy in COPD. Chest. 2012;141:81-6.

24. Kerwin E, Siler T, Tombs L et al. Triple therapy of umeclidinium + inhaled corticosteroids/long-acting $\beta_{2}$ agonists for patients with COPD: pooled results of randomized placebo-controlled trials. Pulm Ther. 2016;2:43-58.
25. Kraemer M, Ellis A, Baldwin M et al. Dual bronchodilation with indacaterol and tiotropium in combination versus triple therapy, fixed-dose combinations, and monotherapy in COPD - a network meta-analysis of $\mathrm{FEV}_{1}$ [abstract] Value Health. 2012; 15:A560.

26. Vincken W, Auman J, Goyal P, Altman P. Free triple combination of glycopyrronium, indacaterol and ICS improves lung function and dyspnoea versus free double combination of indacaterol and ICS in patients with COPD: a post-hoc analysis from the GLOW6 study [abstract]. Eur Respir J. 2014;44:P2410.

27. Lopez-Campos JL, Marquez-Martín E, Ortega-Ruiz F. Triple therapy vs triple therapy in COPD. Arch Bronconeumol. 2017;53:419-20.

28. Manoharan A, Short PM, Anderson WJ, Lipworth BJ. Impact of long-acting bronchodilators and exposure to inhaled corticosteroids on mortality in COPD: a real-life retrospective cohort study. Lung. 2014;192:649-52.

29. Magnussen H, Disse B, Rodriguez-Roisin R et al. Withdrawal of inhaled glucocorticoids and exacerbations of COPD. N Engl J Med. 2014;371:1285-94.

30. Horita N, Kaneko T. Triple therapy vs. dual bronchodilator therapy for chronic obstructive pulmonary disease: Is it worth the cost? Respir Investig. 2015;53:173-5.

31. Cazzola M, Dahl R. Inhaled combination therapy with long-acting $\beta_{2}$-agonists and corticosteroids in stable COPD. Chest. 2004;126:220-37.

32. Calzetta L, Matera MG, Facciolo F et al. Beclomethasone dipropionate and formoterol fumarate synergistically interact in hyperresponsive medium bronchi and small airways. Respir Res. 2018;19:65.

33. Barnes PJ. Glucocorticosteroids. Handb Exp Pharmacol. 2017;237:93-115.

34. Newton R, Giembycz MA. Understanding how long-acting $\beta_{2}$-adrenoceptor agonists enhance the clinical efficacy of inhaled corticosteroids in asthma - an update. Br J Pharmacol. 2016;173:3405-30.

35. Cazzola M, Molimard M. The scientific rationale for combining long-acting $\beta_{2}$-agonists and muscarinic antagonists in COPD. Pulm Pharmacol Ther 2010;23:257-67.

36. Calzetta L, Matera MG, Cazzola M. Pharmacological interaction between LABAs and LAMAs in the airways: optimizing synergy. Eur J Pharmacol. 2015;761:168-73.

37. Cazzola M, Calzetta L, Segreti A et al. Translational study searching for synergy between glycopyrronium and indacaterol. COPD. 2015;12:175-81.

38. Cazzola M, Calzetta L, Ora J et al. Searching for the synergistic effect between aclidinium and formoterol: From bench to bedside. Respir Med. 2015;109:1305-11.

39. Cazzola M, Calzetta L, Rogliani P et al. Interaction between corticosteroids and muscarinic antagonists in human airways. Pulm Pharmacol Ther. 2016 $36: 1-9$.

40. Deb AK, Agarwal M, Reddy V et al. Effects of a fixed dose once-daily triple drug combination in smokers and non-smokers with COPD [abstract]. Eur Respir J. 2016;48 (suppl 60):PA654.

41. Singh D, Schröder-Babo W, Cohuet G et al. The bronchodilator effects of extrafine glycopyrronium added to combination treatment with beclometasone dipropionate plus formoterol in COPD: A randomised crossover study (the TRIDENT study). Respir Med. 2016;114:84-90.

42. Singh D, Papi A, Corradi M et al. Single inhaler triple therapy versus inhaled corticosteroid plus long-acting $\beta_{2}$-agonist therapy for chronic obstructive pulmonary disease (TRILOGY): a double-blind, parallel group, randomised controlled trial. Lancet. 2016;388:963-73.

43. Vestbo J, Papi A, Corradi M et al. Single inhaler extrafine triple therapy versus long-acting muscarinic antagonist therapy for chronic obstructive pulmonary disease (TRINITY): a double-blind, parallel group, randomised controlled trial. Lancet. 2017;389:1919-29.

44. Papi A, Vestbo J, Fabbri L et al. Extrafine inhaled triple therapy versus dual bronchodilator therapy in chronic obstructive pulmonary disease (TRIBUTE): a double-blind, parallel group, randomised controlled trial. Lancet. 2018, 391:1076-84.

45. Brealey N, Gupta A, Renaux J et al. Pharmacokinetics of fluticasone furoate, umeclidinium, and vilanterol as a triple therapy in healthy volunteers. Int J Clin Pharmacol Ther. 2015;53:753-64. 
46. Siler TM, Kerwin E, Sousa AR et al. Efficacy and safety of umeclidinium added to fluticasone furoate/vilanterol in chronic obstructive pulmonary disease: Results of two randomized studies. Respir Med. 2015;109:1155-63.

47. Lipson DA, Barnacle H, Birk R et al. FULFIL trial: once-daily triple therapy for patients with chronic obstructive pulmonary disease. Am J Respir Crit Care Med. 2017;196:438-46.

48. Tabberer M, Lomas DA, Birk R et al. Once-daily triple therapy in patients with COPD: Patient-reported symptoms and quality of life. Adv Ther. 2018;35:56-71.

49. Bremner PR, Birk R, Brealey N et al. Single-inhaler fluticasone furoate/ umeclidinium/vilanterol versus fluticasone furoate/vilanterol plus umeclidinium using two inhalers for chronic obstructive pulmonary disease: a randomized non-inferiority study. Respir Res. 2018;19:19.

50. Lipson DA, Barnhart F, Brealey $\mathrm{N}$ et al. Once-daily single-inhaler triple versus dual therapy in patients with COPD. N Engl J Med. 2018; 378:1671-80.

51. Doty A, Schroeder J, Vang $\mathrm{K}$ et al. Drug delivery from an innovative LAMA/LABA co-suspension delivery technology fixed-dose combination MDI: Evidence of consistency, robustness, and reliability. AAPS PharmSciTech. 2018;19:837-44.

52. Darken P, DePetrillo P, Reisner C et al. The pharmacokinetics of three doses of budesonide/glycopyrronium/formoterol fumarate dihydrate metered dose inhaler compared with active controls: A Phase I randomized, single-dose, crossover study in healthy adults. Pulm Pharmacol Ther. 2018; 50:11-18.

53. Anonymous. PT010 triple combination therapy in chronic obstructive pulmonary disease. Available at: https://www.astrazeneca.com/media-cen tre/press-releases / 2018/astrazeneca-reports-top-line-phase-iii-kronos-trialresults-for-pt010-triple-combination-therapy-in-chronic-obstructive-pul monary-disease-26102018.html. Last accessed March 9, 2018.
54. Wedzicha JA, Banerji D, Chapman KR et al. Indacaterol-glycopyrronium versus salmeterol-fluticasone for COPD. N Engl J Med. 2016;374:2222-34.

55. Cazzola M, MacNee W, Martinez FJ et al. Outcomes for COPD pharmacological trials: from lung function to biomarkers. Eur Respir J. 2008;31: 416-69.

56. Suissa S, Drazen JM. Making sense of triple inhaled therapy for COPD. N Engl J Med. 2018; 378:1723-4. .

57. Cazzola M, Calzetta L, Rogliani P, Matera MG. The challenges of precision medicine in COPD. Mol Diagn Ther. 2017;21:345-55.

58. Vestbo J, Anderson JA, Brook RD et al. Fluticasone furoate and vilanterol and survival in chronic obstructive pulmonary disease with heightened cardiovascular risk (SUMMIT): a double-blind randomised controlled trial Lancet. 2016;387:1817-26.

59. Fabbri LM, Roversi S, Beghé B. Triple therapy for symptomatic patients with COPD. Lancet. 2017;389:1864-5.

60. Pavord ID, Lettis S, Locantore $\mathrm{N}$ et al. Blood eosinophils and inhaled corticosteroid/long-acting $\beta$-2 agonist efficacy in COPD. Thorax. 2016;71:118-25

61. Pavord ID, Lettis S, Locantore $\mathrm{N}$ et al. Blood eosinophils and inhaled corticosteroid/long-acting $\beta$-2 agonist efficacy in COPD. Thorax. 2016;71:118-25

62. Rabe KF, Beghé B, Fabbri LM. Peripheral eosinophil count as a biomarker for the management of COPD: not there yet. Eur Respir J. 2017;50: 1702165.

63. Thomas M, Halpin DM, Miravitlles M. When is dual bronchodilation indicated in COPD? Int J Chron Obstruct Pulmon Dis. 2017;12:2291-2305.

64. Cazzola M, Rogliani P, Matera MG. Escalation and de-escalation of therapy in COPD: Myths, realities and perspectives. Drugs. 2015;75:1575-85.

65. Daley-Yates PT. Inhaled corticosteroids: potency, dose equivalence and therapeutic index. Br J Clin Pharmacol. 2015;80:372-80. 